\title{
Amino Acid Modified Bentonite Clay as an Eco-Friendly Adsorbent for Landfill Leachate Treatment
}

\author{
Matin Hajjizadeh ${ }^{1}$, Shahriar Ghammamy ${ }^{2 *}$, Hossein Ganjidoust ${ }^{3}$, Forough Farsad ${ }^{1}$ \\ ${ }^{1}$ Department of Environmental Science, Faculty of Natural Resources and Environment, \\ Science and Research Branch, Islamic Azad University, Tehran, Iran \\ ${ }^{2}$ Department of Chemistry, Faculty of Science, Imam Khomeini International University, Qazvin, Iran \\ ${ }^{3}$ Environmental Engineering Division, Faculty of Civil and Environmental Engineering, \\ Tarbiat Modares University,Tehran, Iran
}

Received: 8 October 2019

Accepted: 21 November 2019

\begin{abstract}
Bentonite was modified by intercalation of amino acids into its interlayer space. Different amounts of L-glutamic acid were added to bentonite and its effect was investigated on the reduction of landfill leachate contamination. In the best result, the effect of $\mathrm{pH}$ adjustment on the structure and performance of the modified clay was studied. The composite was characterized by various techniques such as FTIR, SEM, XRD, TGA, and BET. Batch experiments were performed to evaluate the factors influencing leachate chemical oxygen demand (COD) and turbidity removal efficiency. The effect of surfactant loading amount, contact time, $\mathrm{pH}$, and adsorbent dosage was evaluated. Under optimum conditions, the maximum COD and turbidity removal rates for row clay were $40.1 \%$ and $63.8 \%$, respectively, but they were $65.7 \%$ and $92.1 \%$ for amino acid-modified clay under $\mathrm{pH}$ adjustment conditions, respectively. Also, the results showed that the adsorbent produced in $\mathrm{pH}$ adjustment conditions had higher efficiency for leachate treatment than the synthesized adsorbent under non-pH adjustment conditions. Under optimum conditions, the percentage of COD and turbidity removal for modified clay under $\mathrm{pH}$ adjustment was $65.7 \%$ and $92.1 \%$, respectively, while they were $61.3 \%$ and $89.9 \%$ for non-pH adjustment, respectively.
\end{abstract}

Keywords: leachate treatment, adsorption, amino acid, modified clay, bentonite

\section{Introduction}

Historically, landfilling has been the oldest form of solid waste management around the world [1] and in many regions due to the simplicity of design and the

*e-mail:shghamami@yahoo.com

low cost of operations, It is still the most common and popular solid waste management strategy [2]. Although this strategy of solid waste management has some advantages, it leads to the production of leachate [3] so that the production of highly contaminated leachate is known as one of the main weaknesses of this type of waste management [4]. Leachate is a liquid that is generated through the percolation of water across the waste layers. This liquid absorbs nutrients and 
pollutants from the waste and accumulates as leachate [5].

Leachate production has become a long-term concern because it releases a wide range of toxic substances, such as heavy metals, inorganic compounds, organic pollutants, and xenobiotic materials [6]. The number of pollutants identified in landfill leachate is much more than those in other parts of the environment including soil, surface water, wastewater, air, and biosolid, which is likely to be associated with the concentration of pollutants in a central location [7]. This dangerous and poisonous leachate affects adjacent areas in the long run [5]. The adverse effects of overloading in susceptible ecosystems have significantly increased the potential of carcinogens were detected in landfill leachates, while these compounds are expected to be sustainable and bioaccumulate [8].

So, leachate treatment and removal of its contaminants have become a major concern in recent decades [5]. Landfill leachate, like wastewater, should be managed during the lifetime of the landfill and also 30 years after its closure [1]. Various methods have been used to remove various contaminations from leachates, such as chemical oxidation, adsorption, chemical precipitation, flocculation and coagulation, aeration/flotation, air stripping, membrane filtration, microfiltration, ultrafiltration, nanofiltration and reverse osmosis. Each of these processes and other methods has its own advantages and disadvantages [5]. At present, the development of conventional techniques is limited due to their high costs, inefficiency, and undesirable rate of removal of contaminants [6].

Adsorption is one of the most effective methods for treating a wide range of wastewater [5]. It is one of the most suitable methods to remove contaminants due to its simplicity of operation, cost-effectiveness, high efficiency, easy adsorbent design, and most importantly, the absence of secondary pollutants during the adsorption process [9].

Commercial adsorbents, such as activated carbon, are very efficient and effective, but they are expensive because of the high costs of production and recovery [10]. Nowadays clay minerals and their modified products are a large family of adsorbents that has now drawn attention because they have relatively low cost and are environmentally friendly [11]. High specific surface area, chemical and mechanical stability, laminar structure, and high ionic exchange capacity have turned clay into super sorbents [12]. These compounds can significantly adsorb different types of contaminants [11]. By removing cations and anions through ion exchange or adsorption, or both, clays play an important role in the environment as a pollutant purifier [12]. Among different types of clay, bentonite is considered as one of the most commonly used adsorbents [10]. We chose bentonite for this study because the bentonite mine was located near the landfill site.

Contaminated water, such as municipal wastewater and landfill leachate, always contains hydrophobic organic compounds and oxyanions. Therefore, it is essential to develop new adsorbents that can simultaneously remove both of these pollutants from wastewaters [13]. Different studies have focused on improving the properties of clay in order to use it as an adsorbent according to its adsorption capacity [14]. Some studies have suggested that the replacement of inorganic interchangeable cations of clay with organic cations can improve the capacity of these materials to remove organic compounds [15].

So far, various chemical agents have been used to modify clay in order to remove contaminants from water and wastewater. The risk of these chemical modifiers is that they may create a serious environmental pollution problem and they usually need an expensive treatment system for unused or additional chemicals [10]. Therefore, it is essential to functionalize clay in a simple method with non-toxic and biodegradable surfactants. Among many functional organic molecules, amino acids are an attractive species for modifying clay compounds [17]. Amino acids are the building blocks of proteins, and some of them are commercially available at affordable prices [17].

Amino acids have amine and carboxyl functional groups while they have side chains in their molecular structure (except for glycine) [18]. On the other hand, amino acid molecules in the solid-state or solution are zwitterionic compounds that contain chemical groups with both positive and negative charges $[16,19]$. In both cases, they allow the formation of hydrogen bonds and create a stable ionic form $\left(\mathrm{R}-\mathrm{CH}\left(\mathrm{COO}^{-}\right) \mathrm{NH}_{3}^{+}\right)$[16]. The use of amino acids to modify inorganic compounds has extensively been studied in recent years. Amino acid-modified compounds have been explored in many fields such as the production of pharmaceuticals and agrochemicals, biomedical sensors, and the synthesis of solid-phase peptides [20]. The use of amino acidmodified clay to reduce environmental pollution is another issue that has recently drawn the attention of researchers.

Singh et al. (1996) investigated the effect of citric acid and glycine on the adsorption of $\mathrm{Hg}^{2+}$ by kaolinite under different $\mathrm{pH}$ conditions. The results of this study showed that glycine, as a chelating agent in kaolinite, is capable of complexing with $\mathrm{Hg}^{2+}$ Two important functional groups, one of the carboxylic group (O-ligand) and the other of the amine group (N-ligand), are responsible for the bonding between $\mathrm{Hg}^{2+}$ and modified kaolinite [21]. Shokri et al. (2017) used arginine to modify montmorillonite and remove anionic contaminants. This study showed that the adsorption capacity of the modified clay for anionic contaminants was five times higher than that of the unmodified clay [22]. Shokri and Yegani (2017) used lysine-modified montmorillonite to remove arsenic from water. The results showed that the removal efficiency was $96 \%$ in optimum conditions and the composite could be recovered and used up to five times [19]. Khaled El Adraa et al. (2017) used cysteine to modify 
montmorillonite and used it to remove heavy metals. The results showed that the modified clay had higher adsorption capacity for the removal of cationic metals such as $\mathrm{Cd}^{2+}, \mathrm{Hg}^{2+}, \mathrm{Pb}^{2+}, \mathrm{Co}^{2+}$ and $\mathrm{Zn}^{2+}$ than the row clay [23]. Pires et al. (2018) used glycine, arginine, and histidine-modified montmorillonite to adsorb $\mathrm{CO}_{2}$ to produce biogas fuel. The results showed that histidine and arginine were more potent adsorbents for $\mathrm{CO}_{2} / \mathrm{CH}_{4}$ removal, and glycine had the lowest $\mathrm{CO}_{2}$ and $\mathrm{CH}_{4}$ adsorbent [17].

Since the length of the organic modifier chain has a significant effect on the structure, crystallinity, and nanomechanical properties of the clay polymer composites (PCN) [24], we, therefore, chose a longchain amino acid as the modifier. For this reason, in this study, among different surfactants with the amine group, L-glutamic acid was used as a promising modifier for bentonite. L-glutamic acid has five carbon chains $\left(\mathrm{C}_{5} \mathrm{H}_{9} \mathrm{O}_{4} \mathrm{~N}\right)$ and is one of the most widely used biological amino acids. Due to its fundamental properties, its application has extensively been studied in various fields of biochemistry, medicine, food, and pharmaceutical industries [25]. But, no study has yet been done on its effects on the removal of contaminants.

The main purpose of the present study was to investigate the effect of L-glutamic acid-modified bentonite on reducing the amount of organic contamination and turbidity of leachate and to explore the structural changes caused by clay modification with L-glutamic acid. The concentration of this surfactant was variable from $0.25 \mathrm{CEC}$ to $3 \mathrm{CEC}$, and XRD, FTIR, TGA, and BET analyses were used to identify the modified clay. As well, the effect of various parameters such as $\mathrm{pH}$, contact time, and adsorbent dosage was investigated on reducing the amount of leachate contamination. We modified bentonite with amino acids for the first time to improve the efficiency of the removal of leachate contamination.

\section{Materials and Methods}

\section{Landfill Leachate}

The leachate samples used in this study were obtained from the evaporation lagoons in the sanitary landfill of Mohammad Abad located $25 \mathrm{~km}$ south of Qazvin, Iran. The site covers an area of 110 ha and receives approximately 750 tons of municipal solid waste per day. This landfill has been operating since May 2013 and was expected to have 20 years of life span. The leachate was collected in clean glass bottles and was immediately transported to a laboratory in ice $\left(4^{\circ} \mathrm{C}\right)$ and in a dark environment to prevent chemical degradation. The sampling of the leachate was repeated weekly and the average was taken. The characteristics of the landfill leachate samples are presented in Table 1.

\section{Materials}

Bentonite was obtained from the Avaj mine in Qazvin province. To remove contaminations and dust, it was washed with deionized water and dried in an oven. The cation exchange capacity (CEC) of the clay was $40 \mathrm{meq} / 100 \mathrm{~g}$, which was calculated using the copper bisethylenediamine complex method. The composition of the bentonite used in this study is presented in Table 2.

Table 1. Characteristics of the leachate samples.

\begin{tabular}{|c|c|c|c|c|c|}
\hline Parameter & Unit & Average Value & Parameter & Unit & Average Value \\
\hline COD & $\mathrm{mg} / \mathrm{L}$ & 185907 & Lead & $\mathrm{ppm}$ & 0.5 \\
\hline BOD $_{5}$ & $\mathrm{mg} / \mathrm{L}$ & 40500 & Zinc & $\mathrm{ppm}$ & $<1.5$ \\
\hline Turbidity & & 1673 & Arsenic & $\mathrm{ppm}$ & 1.1 \\
\hline $\mathrm{pH}$ & ------- & 7.4 & Cadmium & $\mathrm{ppm}$ & $<0.03$ \\
\hline Aluminum & $\mathrm{ppm}$ & 2.5 & Mercury & $\mathrm{ppm}$ & $<0.6$ \\
\hline Cobalt & $\mathrm{ppm}$ & $<0.5$ & Total Iron & $\mathrm{ppm}$ & 12.5 \\
\hline Chromium & $\mathrm{ppm}$ & $<0.5$ & Calcium & $\mathrm{ppm}$ & 10047.6 \\
\hline Copper & $\mathrm{ppm}$ & $<0.2$ & Potassium & $\mathrm{ppm}$ & 3988.97 \\
\hline Manganese & $\mathrm{ppm}$ & 1.9 & Sodium & $\mathrm{ppm}$ & 9918.4 \\
\hline
\end{tabular}

Table 2. Composition of Bentonite.

\begin{tabular}{|c|c|c|c|c|c|c|c|c|c|c|c|}
\hline Sample & $\mathrm{SiO}_{2}$ & $\mathrm{Al}_{2} \mathrm{O} 3$ & $\mathrm{Fe}_{2} \mathrm{O}_{3}$ & $\mathrm{CaO}$ & $\mathrm{Na}_{2} \mathrm{O}$ & $\mathrm{MgO}$ & $\mathrm{K}_{2} \mathrm{O}$ & $\mathrm{TiO}_{2}$ & $\mathrm{MnO}$ & $\mathrm{P}_{2} \mathrm{O}_{5}$ & $\mathrm{LOI}$ \\
\hline Percentage & 67.046 & 11.72 & 1.737 & 3.253 & 0.95 & 3.391 & 3.028 & 0.138 & 0.047 & 0.031 & 8.6 \\
\hline
\end{tabular}


The amino acid that was used to prepare this organoclay was L-glutamic acid $\left(\mathrm{C}_{5} \mathrm{H}_{9} \mathrm{NO}_{4}\right)$ with a purity of $99 \%$, which was purchased from Merck Company.

The $\mathrm{pH}$ of the leachate was adjusted by adding $1 \mathrm{M}$ $\mathrm{HCl}$ and $\mathrm{NaOH}$ using the WTW pH meter. All other chemicals used were analytical grades and were used without further purification. All solutions were prepared with distilled water.

\section{Purification of Bentonite}

To purify the clay, a certain amount of bentonite was dispersed into distilled water and the mixture was agitated by a stirrer at $250 \mathrm{rpm}$ for 24 hours at room temperature. It was then centrifuged for at $4000 \mathrm{rpm}$ 20 minutes. The purified bentonite was then oven-dried at $45^{\circ} \mathrm{C}$ for 48 hours.

\section{Synthesis of Adsorbent}

The ion exchange method was used to modify the clay by replacing the interchangeable cations of bentonite with protonated amino acids. So, $30 \mathrm{~g}$ of bentonite was dispersed in $300 \mathrm{ml}$ of deionized water, and the mixture was agitated by a magnetic stirrer for about 30 minutes to swell the clay. In another container, a stoichiometric amount of amino acid was poured in distilled water and the $\mathrm{pH}$ of the solution was adjusted to 2 by adding 0.1 molar $\mathrm{HCl}$. To dissolve the amino acid, the solution was stirred at $60^{\circ} \mathrm{C}$ for about 30 minutes.

To study the effect of $\mathrm{pH}$ on the modification of bentonite, the above steps were repeated without $\mathrm{pH}$ adjustment. In the absence of $\mathrm{pH}$ adjustment, at $3 \mathrm{CEC}$, the $\mathrm{pH}$ of the L-glutamic acid solution was 3.5. Then, the dissolved amino acid was slowly added into the bentonite suspension at $60^{\circ} \mathrm{C}$. The mixture was stirred at $60^{\circ} \mathrm{C}$ for about 4 hours using a magnetic stirrer. Then, the modified bentonite was centrifuged and washed several times with DI water. Washing was repeated several times to remove excess ammonium salts. The final composite was oven-dried at $60^{\circ} \mathrm{C}$ for 48 hours. The dried organoclay was converted into nanoparticles using a planetary ball mill (120 rpm for 15 hours). The particle size was calculated to be about $27.8 \mathrm{~nm}$ by using the Scherrer equation. The final product was stored in a plastic container for later use.

\section{Characterization and Analysis}

To characterize the prepared composites, different characterization techniques were used. The surface morphology of the raw and modified bentonite was examined by a scanning electron microscope (FESEMMIRA3). The functional groups and chemical structure of the nanoclay, was characterized before and after modification by FTIR spectrum in the range $400-4000 \mathrm{~cm}^{-1}$. The IR technique is a basic method for detecting the position of surfactant molecules loaded in an interlayer space of clay. Structural geometry, crystallinity, and basal spacing $\left(\mathrm{d}_{001}\right)$ of raw and modified bentonite were determined by using X-ray diffraction. The XRD patterns were recorded at room temperature on a Philips, PW1730 model with Cuka radiation $(\lambda=1.541874 \AA)$ at $40 \mathrm{kV}$ and $150 \mathrm{~mA}$ in the range of $1-80^{\circ}$ and a scan speed of $2 \% \mathrm{~min}$. The thermogravimetric analysis of the clay and organoclay was carried out using a TA Instrument Inc. Q600 at a ramp of $10^{\circ} \mathrm{C} / \mathrm{min}$ from room temperature to $1000^{\circ} \mathrm{C}$ under a high-purity flowing nitrogen atmosphere. Specific

a)

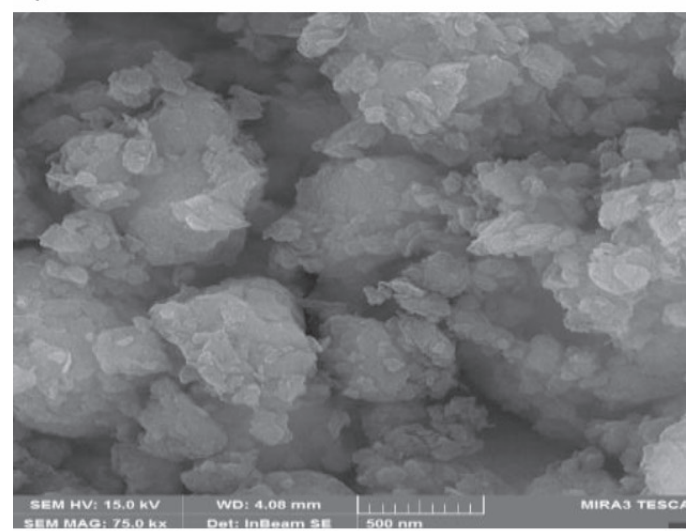

b)

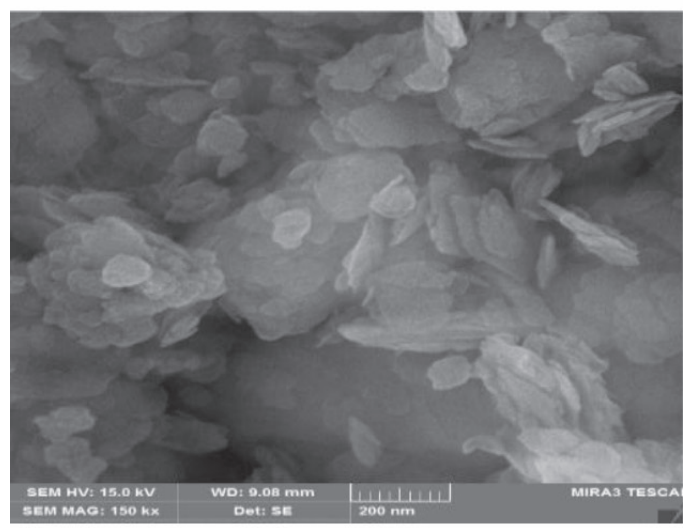

c)

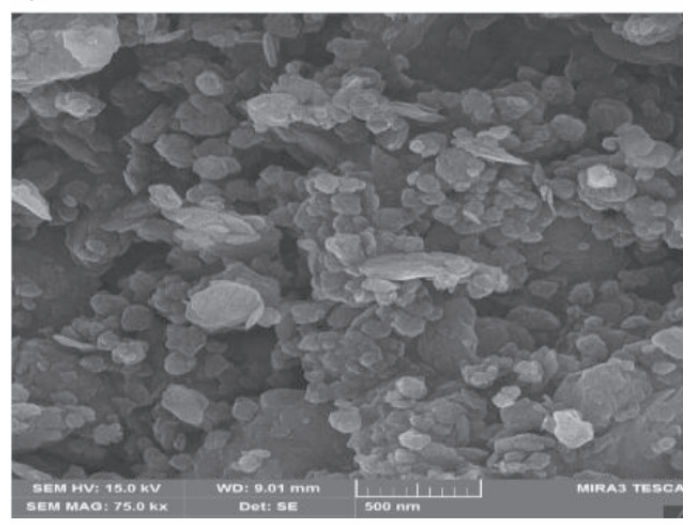

Fig. 1. a) Scanning electron microscopy of bentonite, b) SEM of Glu-bentonite in non-pH conditions, and c) SEM of Glubentonite in $\mathrm{pH}$ conditions. 
surface area, porosity, and average pore diameter were obtained using the Brunauer-Emmett-Teller (BET) method in the presence of $\mathrm{N}_{2}$ (BEISORP MINI II, Japan). The samples were previously degassed for 12 hours.

\section{Results and Discussion}

\section{SEM}

The SEM technique was used to illustrate the morphology of the raw and modified clay. Fig. 1 shows the SEM images of the unmodified and modified bentonite. The raw bentonite has bulky and massive morphology. Compared to the raw bentonite, the bentonite modified with L-glutamic acid (in both $\mathrm{pH}$ and non-pH conditions) shows more pieces with smaller plates.

On the other hand, Glu-BEN in both $\mathrm{pH}$ and non$\mathrm{pH}$ adjustment conditions shows a rougher morphology. This change is influenced by the molecular interactions of the compounds present in the organoclay, so it can be said that after modification, the dense stacking sheets are broken and the sample surface becomes rough [9]. that this confirms our assumption.

Due to the hydrophilic properties of the clay sheets and the hydrophobic properties of the surfactant, it is predicted that severe repulsion will occur between the groups [26]. The presence of amino acids increases the interlayer spacing and creates a more open morphology.
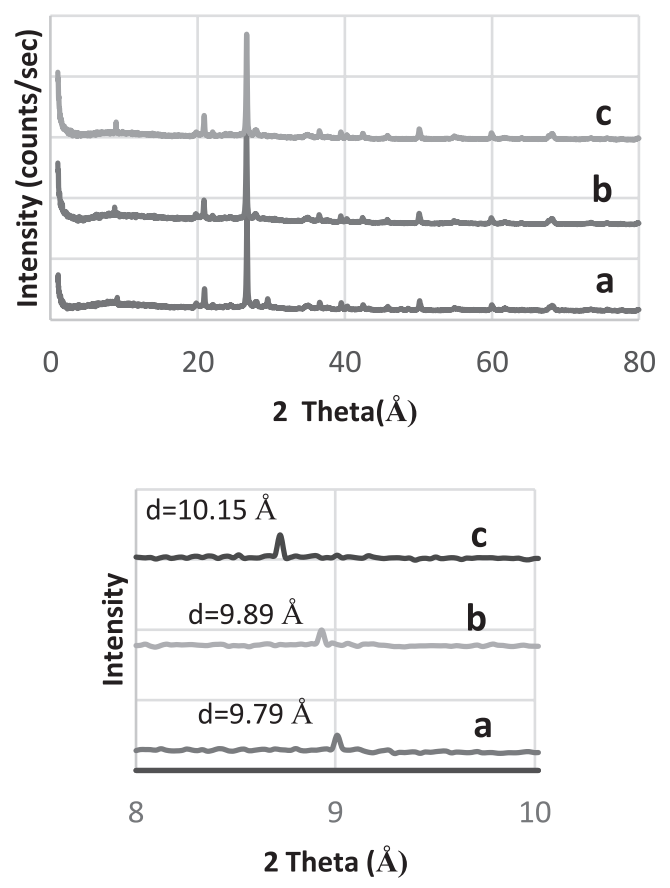

Fig. 2. XRD pattern of a) bentonite, b) bentonite intercalated with L-glutamic acid in non-pH adjustment conditions, and c) bentonite intercalated with L-glutamic acid in $\mathrm{pH}$ adjustment conditions.
Therefore, the results of SEM analysis are corroborated by the results of the XRD analysis, which shows an increase in the basal spacing in the modified clay compared to the raw clay. However, determining the exact impact of $\mathrm{pH}$ on clay properties requires the use of other techniques such as XRD, FTIR, and BET, and SEM alone cannot reflect this change.

\section{XRD}

The XRD pattern of the original and modified bentonite are compared in Fig. 2. Clays are always mixed with non-clay minerals, which can cause intense peaks even in small amount [27]. As shown in Fig. 2, the clay is not pure bentonite. The most intense peak is seen at $2 \theta=26.69$, which is due to the presence of quartz. The results of the XRD diffractogram show that bentonite of the Avaj region is rich in non-clay phases and it consists of four minerals including quartz, calcite, illite, and albite. Bentonite has a basal spacing of about $9.79 \AA$ which, after functionalization with L-glutamic acid, changes to $10.15 \AA$ in the $\mathrm{pH}$ adjustment conditions and to $9.89 \AA$ in the non-pH adjusted state. These results indicate that the basal space of bentonite is increased as the $\mathrm{pH}$ of synthesis is decreased.

Increasing the basal space is often attributed to the successful loading of amino acid molecules in the interlayer space of clay [22]. However, more evidence is needed to confirm the absorption of amino acid molecules. Because the assumption resulting from the change in the basal spacing obtained from the XRD results does not provide complete information on local conformation and phase state of the loaded amino acid [2]. Therefore, it is necessary to perform TGA and FTIR analyses.

On the other hand, theoretically, the loading mechanism changes the reflection of pages $d_{001}$ to lower angles [28]. This is consistent with the results of the experiments. The results indicate that the peak of pages $\mathrm{d}_{001}$ in the raw bentonite is observed at $2 \theta=9.01$, which shifted to $2 \theta=8.70$ after modification by L-glutamic acid under $\mathrm{pH}$ adjustment conditions and shifted to $2 \theta=8.93$ under non-pH adjustment conditions. The reason for creating the peaks at lower angles after functionalization is not completely clear, but more than loading can be attributed to the relative purity of clay.

\section{FTIR}

FTIR is an essential technique for determining the qualitative characteristics of adsorbent's functional groups [29]. The intercalation of amino acid was investigated by the FTIR spectroscopy. The infrared spectrum of the raw and modified bentonite at $4000-400 \mathrm{~cm}^{-1}$ wavenumbers is shown in Fig 3. The raw bentonite has bands at 3626, 3401, 2372, 1643, 1439, 1028, 793, 690, 520, and $470 \mathrm{~cm}-1$, as depicted in Fig. 3. The internal hydroxyl groups, between the octahedral and tetrahedral layers, are clearly visible at $3626 \mathrm{~cm}^{-1}$ 


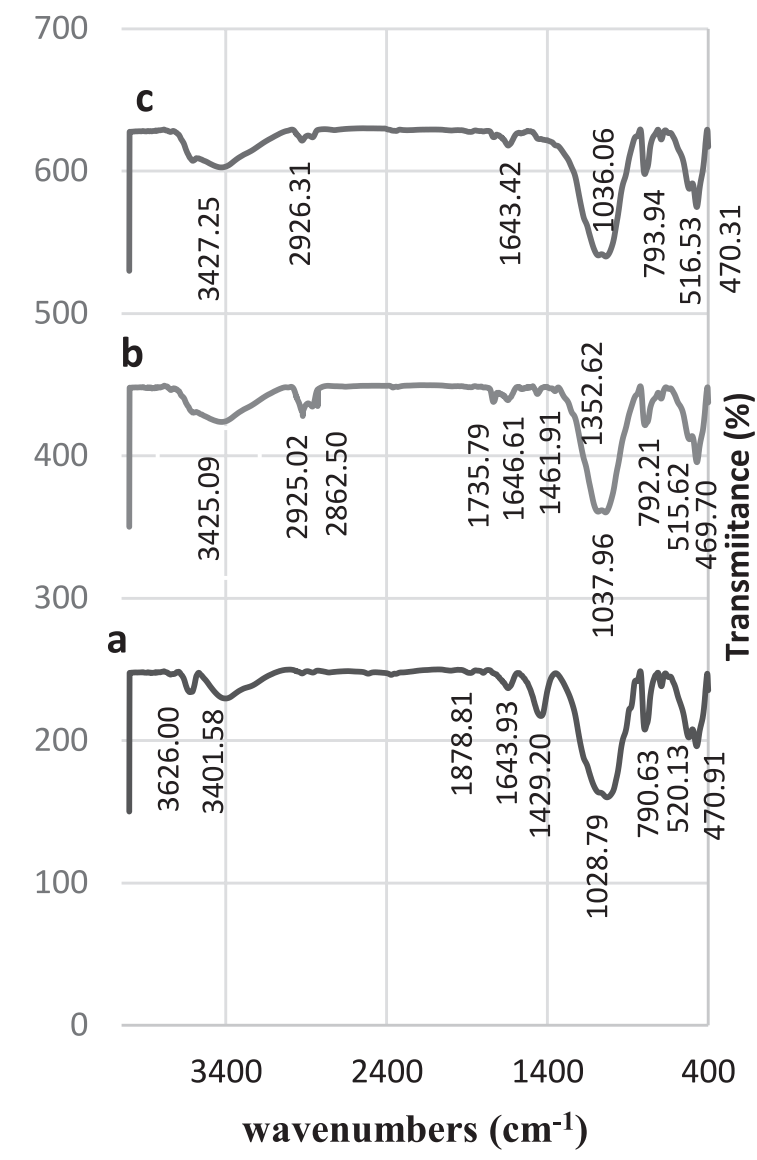

Fig. 3. FTIR pattern of a) bentonite, b) Glu-bentonite in non-pH conditions, and c) Glu-bentonite in $\mathrm{pH}$ conditions.

[30]. This band is eliminated after modification with L-glutamic acid in both conditions of $\mathrm{pH}$ adjustment and non-pH adjustment. This change is probably due to the fact that water molecules are replaced by loaded amino acids in the interlayer space of clay [14,31]. Removing hydrogen bands in the modified clay indicates the change in surface properties of clay from hydrophilic to hydrophobic [31, 32]. Changing the surface properties of clay from hydrophilic to hydrophobic in the preparation of modified clay may lead to an increase in adsorption capacity to hydrophobic non-ionic contaminations [32].

On the other hand, adsorption bands at 3401 and $1643 \mathrm{~cm}^{-1}$ are probably attributed to the $-\mathrm{OH}$ stretching and bending vibration, which is related to water molecules adsorbed on the surface of the clay $[9,30]$. After modification of the clay by amino acid, the intensity of these bands was increased to 3425 and $1646 \mathrm{~cm}^{-1}$ for the modified clay in the $\mathrm{pH}$ adjustment conditions and to 3427 and $1643 \mathrm{~cm}^{-1}$ for the modified clay in the non-pH adjustment conditions.

The presence of carbonate was detected by the band at $1450-1410 \mathrm{~cm}^{-1}$, which confirms the presence of calcite in the sample [30]. In the raw bentonite, this peak was seen at $1439 \mathrm{~cm}^{-1}$ but in the clay modified with the amino acid in the $\mathrm{pH}$ adjustment conditions, it was shifted to $1461 \mathrm{~cm}^{-1}$ and in the non-pH adjustment conditions, it was disappeared.
The bentonite infrared spectrum also has a band at $1028 \mathrm{~cm}^{-1}$, which is attributed to the $\mathrm{Si}-\mathrm{O}-\mathrm{Si}$ bending vibrations $[14,23,30]$. Quartz bands $(\mathrm{Si}-\mathrm{O})$ are close to $790 \mathrm{~cm}^{-1}[9,14,24,33]$, and the bands at 520 and $470 \mathrm{~cm}^{-1}$ are assigned to the O-Si-O bending vibrations [33].

The modification of clay with L-glutamic acid under the $\mathrm{pH}$ adjustment conditions leads to the formation of bands at 2862, 2925, 1735, and $1352 \mathrm{~cm}^{-1}$. However, the clay modification under the non-pH adjustment conditions leads to the appearance of only a new peak at $2926 \mathrm{~cm}^{-1}$.

Bonds at 2862 and $2925 \mathrm{~cm}^{-1}$ are attributed to the symmetric and asymmetric stretching vibrations of $\mathrm{CH}_{2}$, respectively [33]. The band at $1735 \mathrm{~cm}^{-1}$ refers to the presence of amino acids in the modified clay. This band is attributed to the stretching vibrations of the $\mathrm{C}=\mathrm{O}$ carboxylic groups in amino acids $[17,34]$. The presence of the carboxylic acid group in the clayamino acid composite is probably due to the hydrogen bond formed between the carboxylic acid and the amine group in the side chain. This finding confirms the stability of the amino acid-modified compounds by hiding the negative charge of carboxylic acid through intermolecular hydrogen bonding [17]. The band at $1352 \mathrm{~cm}^{-1}$ is likely to be devoted to the symmetric stretching of $\mathrm{CH}_{3}$ in the $\mathrm{NHCOCH}_{3}$ group.

In other words, the FTIR spectrum in Glu-BEN under the $\mathrm{pH}$ adjustment conditions shows peaks, which are attributed to both BEN and Glu functional groups in their pristine state. while, under the non- $\mathrm{pH}$ adjustment conditions, some Glu peaks are not observed. Notable IR peaks attributed to Glu include the $\mathrm{C}=\mathrm{O}$ stretching bands, the $\mathrm{CH}_{2}$ symmetric and asymmetric stretching bands, and the N-H stretching bands. On the other hand, the significant IR peaks attributed to bentonite include the $-\mathrm{OH}$ and $\mathrm{Si}-\mathrm{O}$ and $\mathrm{Al}-\mathrm{O}$ stretching/bending bands.

\section{TGA}

Fig. 4 shows the thermogravimetric (TGA) curve of the raw and modified clay from room temperature to $1000^{\circ} \mathrm{C}$ under inert conditions. As is evident in the figure, the thermal stability of the unmodified clay is higher than that of the modified clay.

Two stages of mass loss were observed for the raw bentonite. The first stage is from room temperature to about $200^{\circ} \mathrm{C}$, which results in a slight decrease in the weight of the clay. This weight loss is attributed to the loss of moisture. After the temperature rises to about $400^{\circ} \mathrm{C}$, the weight is almost constant. From $400^{\circ} \mathrm{C}$ to about $800^{\circ} \mathrm{C}$, the weight again decreases due to the dehydroxylation of the clay or the release of interchangeable water coordinated to cations $[11,14,17$, 35].

In the thermogram (Fig. 4), as seen in organoclay, weight loss occurs in three stages in both the $\mathrm{pH}$ and non-pH conditions $[11,36]$. The first stage is similar to the bentonite and occurs at room temperature up to about $240^{\circ} \mathrm{C}$, which is attributed to the loss of absorbed 


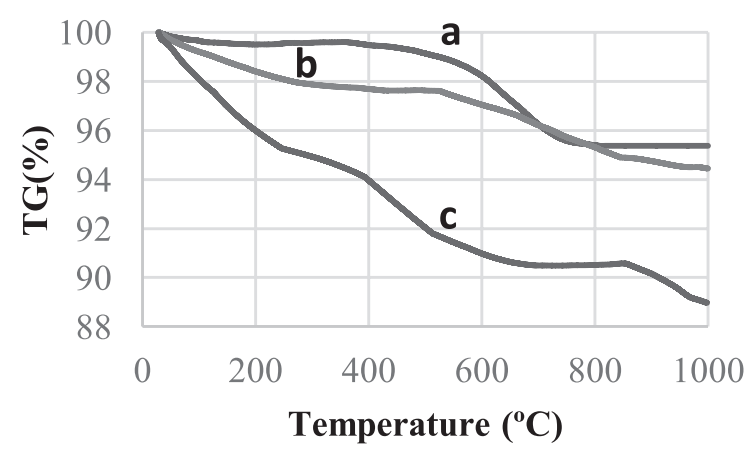

Fig. 4. The TG pattern of a) bentonite, b) Glu-bentonite in non$\mathrm{pH}$ conditions, and c) Glu-bentonite in $\mathrm{pH}$ conditions.

Table 3. Contents of the amino acids.

\begin{tabular}{|c|c|c|c|}
\hline \multirow{2}{*}{ Glu-BEN } & $\mathrm{pH}$ & Conditions & $\begin{array}{c}(\mathrm{wt} \%) \\
\text { Amino acid content }\end{array}$ \\
\cline { 2 - 4 } & 2 & $\mathrm{pH}$ adjusting & 5.33 \\
\cline { 2 - 4 } & 3.5 & non-pH adjist & 3.7 \\
\hline
\end{tabular}

surface water [17]. The second stage is from $240^{\circ} \mathrm{C}$ to $825^{\circ} \mathrm{C}$, which can be attributed to the oxidative decomposition of the amino acid [17]. The contents of the amino acid determined from this stage of weight loss are summarized in Table 3. The third stage (above $825^{\circ} \mathrm{C}$ ) is assigned to the loss of structural hydroxyl groups of clay $[11,36]$.

\section{BET}

Specific surface area and porosity of an adsorbent are significant parameters in determining adsorption capacity and the efficiency of an adsorbent [37].

In this study, the Brunauer-Emmet-Teller (BET) analyzer was used to determine the pore size and surface area. Table 4 shows the list of surface area, pore volume (porosity), and the average pore diameter of the raw and modified bentonite in the $\mathrm{pH}$ adjustment and non-pH adjustment conditions.

Under the $\mathrm{pH}$ adjustment conditions, the modified bentonite has a higher surface area than the raw bentonite. However, in the non-pH adjustment conditions, the specific surface area decreases after modification. This is probably due to the fact that in the non-pH adjustment conditions, the interlayer space of the clay is blocked by surfactant molecules, which leads to a reduction in the number of active sites available for absorbing $\mathrm{N}_{2}$ gas [14, 32, 33]. But, in the $\mathrm{pH}$ adjustment conditions, new pores are likely to be created which leads to an increase in the specific surface area.

By adding amino acids, pore volume and average pore diameter increase in both the $\mathrm{pH}$ and non$\mathrm{pH}$ adjustment conditions. This is the result of the expansion of the interlayer space of the clay by organic compounds and the formation of interlamellar smalldiameter pores [32].

For the raw and modified clay, the pore diameter distribution of mesopores can be computed using the BJH (Barret-Joyner-Halenda) method of adsorption branches [9]. The raw and modified clay pores both appear at $1.29 \mathrm{~nm}$.

\section{Adsorption Experiment}

Batch adsorption studies were performed to determine the adsorption capacity of the raw and modified clay. In this study, the effect of parameters including the amount of intercalated surfactant (0.25 -3 CEC), contact time (20-100 min), $\mathrm{pH}(11-2)$ and adsorbent dosage $(10-40 \mathrm{gr} / \mathrm{L})$ was investigated on the COD and turbidity removal of the landfill leachate.

All the adsorption studies were carried out in a $100 \mathrm{ml}$ beaker, containing $50 \mathrm{ml}$ of landfill leachate and the desired dosage of adsorbent at different $\mathrm{pH}$ 's and contact times at room temperature and the rotating speed of $150 \mathrm{rpm}$. At the end of a predetermined time, the suspension was centrifuged at $3500 \mathrm{rpm}$ for 15 minutes and the supernatant was analyzed. To measure the turbidity, a WTW turbidity meter (Turb550) was used. The chemical oxygen demand (COD) was determined a standard method.

All experiments were repeated three times and the average values were considered. The standard deviation for triple tests in all experiments was less than $0.7 \%$. The removal percentage of contaminants (R\%) was calculated from the following equation:

$$
R(\%)=\frac{C_{0}-C_{e}}{C_{0}} * 100
$$

...where $C_{0}$ and $C_{e}$ are the initial and final concentration, respectively and $R$ is the removal efficiency (COD and turbidity).

Table 4. Textural characteristics of clay and modified clays.

\begin{tabular}{|c|c|c|c|c|}
\hline & Surface area $\mathrm{S}_{\mathrm{BET}}\left(\mathrm{m}^{2} / \mathrm{g}\right)$ & Total pore Volume $\left(\mathrm{C}^{3} / \mathrm{g}\right)$ & Mean diameter $(\mathrm{nm})$ & $\mathrm{BJH}(\mathrm{nm})$ \\
\hline Bentonite & 28.981 & 0.1158 & 15.982 & 1.29 \\
\hline $\begin{array}{c}\text { Glu-BEN } \\
\text { By pH adjusting }\end{array}$ & 30.512 & 0.1308 & 17.152 & 1.29 \\
\hline $\begin{array}{c}\text { Glu-BEN } \\
\text { Non-pH adjusts }\end{array}$ & 20.678 & 0.1226 & 23.709 & 1.29 \\
\hline
\end{tabular}




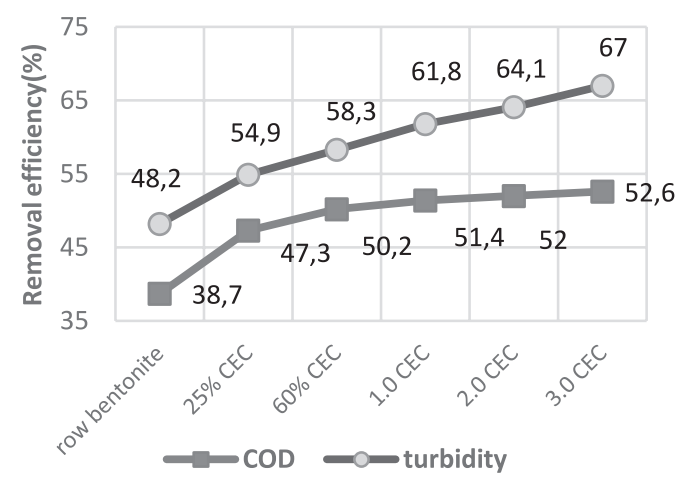

Fig. 5. Optimal amount of modifier.

In this research, the $\mathrm{pH}$ of the leachate was adjusted using a 1molar solution of $\mathrm{HCl}$ and $\mathrm{NaOH}$.

\section{Determining the Optimal Amount of Modifier}

To evaluate the optimal amount of the modifier, the bentonite was intercalated with different values of L-glutamic acid from $0.25 \mathrm{CEC}$ to $3 \mathrm{CEC}$, and the percentage of COD and turbidity removal of landfill leachate was examined. The results (Fig. 5) showed that the highest removal percentage for both parameters was obtained at 3.0 CEC. It is worth noting that this step was carried out under the non-pH adjusting conditions and after determining the optimal amount of surfactant loaded, the other steps were performed in both the $\mathrm{pH}$ adjustment and non-pH adjustment conditions.

a)

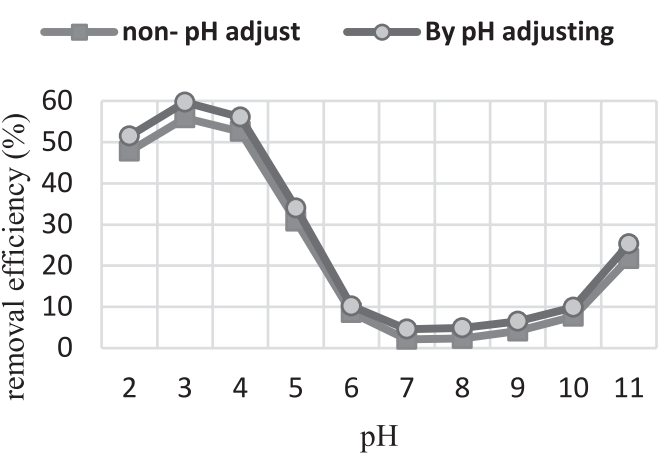

b)

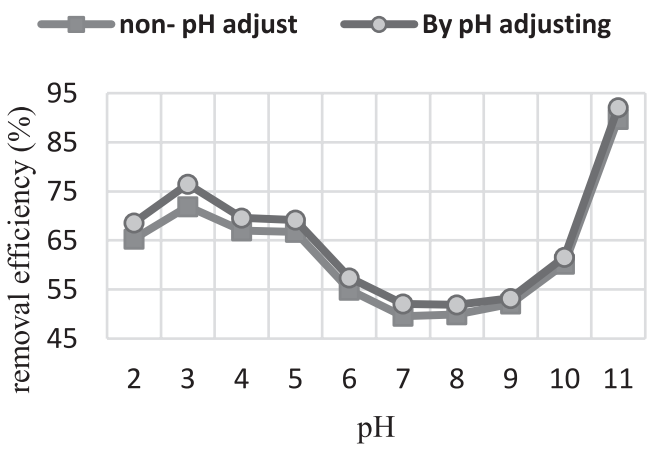

Fig. 6. Effect of $\mathrm{pH}$ on a) COD and b) turbidity removal.

\section{Effect of $\mathrm{pH}$}

The $\mathrm{pH}$ of an aqueous solution is an important factor that can affect adsorption. The $\mathrm{pH}$ of an aqueous solution can affect the degree of ionization and the formation of various pollutants, which ultimately changes the reaction kinetics and equilibrium of the adsorbing process [38].

To study the adsorption mechanism, the $\mathrm{pH}$ range of 2-11 at 30 minutes and the adsorbent dosage of 40 $\mathrm{g} / 1$ were used. The effect of $\mathrm{pH}$ on the reduction of COD and turbidity with the L-glutamic acid modified clay under the $\mathrm{pH}$ adjustment and non-pH adjustment conditions is shown in Fig. 6.

As is evident in Fig. 6, it is clear that the removal of COD and turbidity in both adsorbents depends on the $\mathrm{pH}$ value. In both adsorbents, the removal of COD is improved under acidic conditions and reaches its maximum at $\mathrm{pH}=3$. When the $\mathrm{pH}$ rises above 4, adsorption gradually decreases and reaches its minimum at $\mathrm{pH}=7$. These results can be explained by the surface charge of the clay. In the external surface of the bentonite, siloxane groups $(\mathrm{Si}-\mathrm{O})$ and tetrahedral sheets are weaker and converted to $\mathrm{Si}-\mathrm{O}$ bands, which later become $\mathrm{Si}-\mathrm{OH}$ with $\mathrm{pH}$ changes [29]. As the $\mathrm{pH}$ rises to alkalinity, again COD removal gradually increases as precipitation occurs.

In the case of turbidity, the highest removal occurs at $\mathrm{pH}=11$, which can be attributed to simultaneous adsorption and precipitation. Therefore, $\mathrm{pH}=3$ for

a) non- $\mathrm{pH}$ adjust $\longrightarrow$ By $\mathrm{pH}$ adjusting

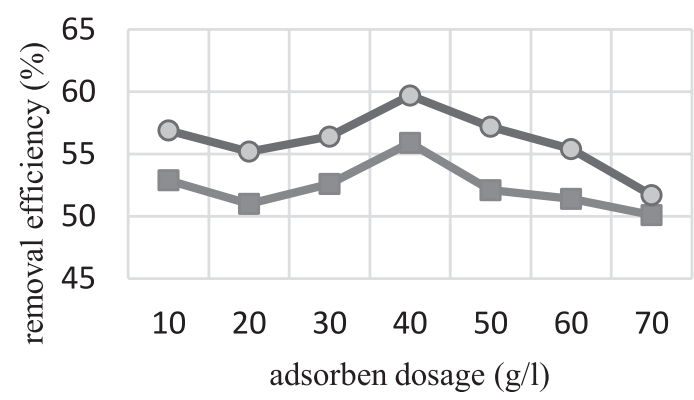

b) - non- $\mathrm{pH}$ adjust $\quad-\mathrm{By} \mathrm{pH}$ adjusting

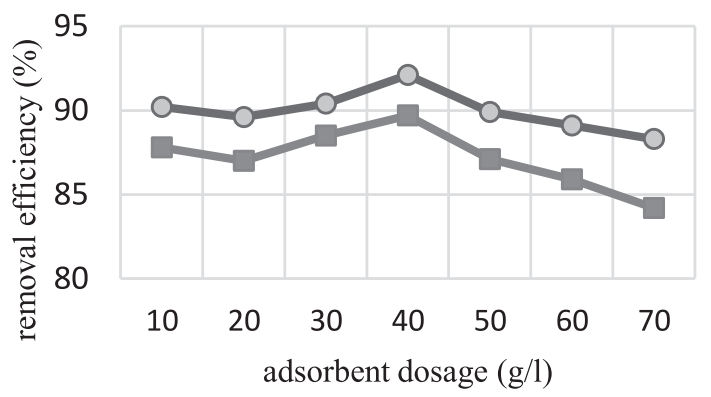

Fig. 7. Effect of adsorbent dosage on a) COD and b) turbidity removal. 
a)

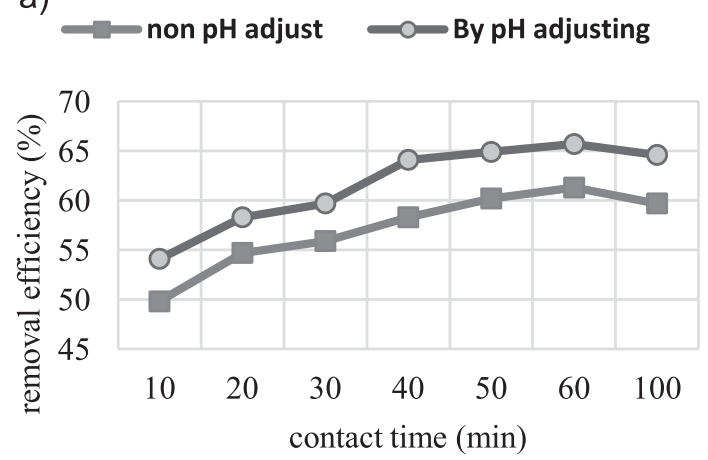

b)

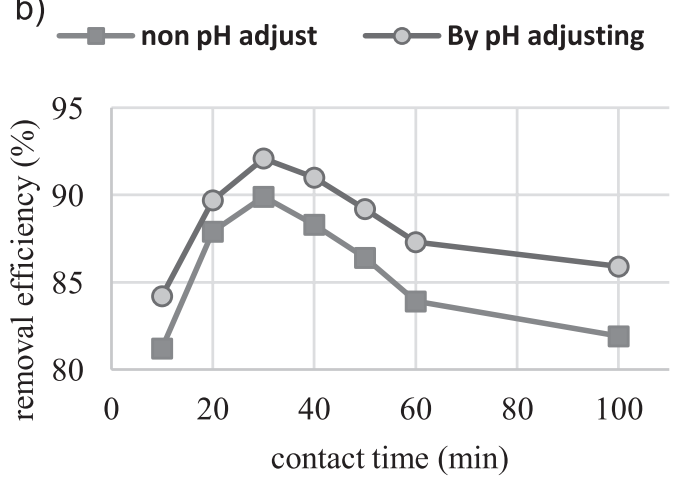

Fig. 8. Effect of contact time on a) COD and b) turbidity removal.

$\mathrm{COD}$ and $\mathrm{pH}=11$ for turbidity were selected for further study.

\section{Effect of Adsorbent Dosage}

Fig. 7 displays the effect of adsorbent dosage (in the range of 10-70 $\mathrm{gr} / \mathrm{L}$ ) to reduce COD and turbidity at the optimal $\mathrm{pH}$. It is observed that by increasing the adsorbent dosage, the efficiency of COD and turbidity removal increases for both adsorbents. This can be simply attributed to an increase in the surface area of absorbents and the availability of more adsorption sites [37].

The COD and turbidity reach its maximum at $40 \mathrm{~g} / \mathrm{L}$, and then it decreases with increasing the amount of adsorbent. This decrease may be due to the overlap of the adsorption sites because of the over-crowd of the adsorbent particles [38].

\section{Effect of Contact Time}

In any batch system, contact time plays a vital role in COD reduction [39]. As can be seen in Fig. 8, with the increase in contact time, the COD and turbidity removal efficiencies were gradually increased and then stopped after a certain time. The maximum COD reduction efficiency was achieved in $60 \mathrm{~min}$ and the maximum turbidity reduction rate was obtained in $30 \mathrm{~min}$. Much more adsorption in the early stages can be attributed to the availability of accessible sites during the early stage and the remaining empty sites were hard to occupy due to the repulsive forces between the dissolved molecules and solids phase when it comes to equilibrium [40].

\section{Conclusions}

In this research, a simple, efficient and environmentally friendly method was used to prepare a natural organoclay. Bentonite was modified by L-glutamic acid under $\mathrm{pH}$ adjustment and non-pH adjustment conditions and its effect was studied on reducing the contamination of landfill leachate. The FTIR, XRD, SEM, BET, and TGA analyses confirmed that amino acid was well intercalated on the bentonite. The results of the batch experiments showed that the $\mathrm{pH}$ of the solution, the amount of composite, and the contact time affect the COD and turbidity of landfill leachate. The results of the experiments also indicated that the composite prepared under the $\mathrm{pH}$ adjustment conditions was a more suitable adsorbent for COD and turbidity removal of landfill leachate compared to modified clay in the non-pH adjustment conditions. The results confirmed that the clay modified by L-glutamic acid could reduce COD and turbidity of landfill leachate. The maximum removal efficiency of COD for amino acid-modified clay under the $\mathrm{pH}$ adjusting and non-pH adjusting conditions was 65.7 and $61.3 \%$, respectively, and the maximum removal rate for turbidity in the $\mathrm{pH}$ adjusting and non-pH adjusting conditions was $92.1 \%$ and $89.9 \%$, respectively under optimum conditions. Due to the low ion exchange capacity of the clay used in this study (40 meq/100 gr), it can be concluded that the removal rate of leachate pollutants increases with the use of high ion exchange clay. These results show that the use of amino acids for organoclay preparation can limit the use of toxic and conventional organic compounds and provide a clean and environmentally friendly technology for the synthesis of nanocomposites. Briefly, L-glutamic acidmodified bentonite can be used as an efficient and economical adsorbent to remove COD and turbidity from landfill leachate.

\section{Acknowledgements}

The authors would like to express their gratitude to Alborz Industrial City and Alborz Wastewater Treatment Plant for the support of this study by providing the laboratory conditions.

\section{Conflict of Interest}

The authors declare that they have no conflict of interest. 


\section{References}

1. GANESH K., JAMBECK J. Treatment of landfill leachate using microbial fuel cells: Alternative anodes and semicontinuous operation. Bioresource Technology, 139, 383, 2013.

2. FOO K.Y., LEE L.K., HAMEED B.H. Preparation of tamarind fruit seed activated carbon by microwave heating for the adsorptive treatment of landfill leachate: A laboratory column evaluation. Bioresource Technology, 133, 599, 2013.

3. MOJIRI A., ZIYANG L., RAMLAH MOHD TAJUDDIN R.M., FARRAJI H., ALIFAR N. Co-treatment of landfill leachate and municipal wastewater using the ZELIAC/zeolite constructed wetland system. Journal of Environmental Management, 166, 124, 2016.

4. DELKASH M., BAKHSHAYESH B.E., KAZEMIAN H. Using zeolitic adsorbents to clean up special wastewater streams: A review. Microporous and Mesoporous Materials, https://doi.org/10.1016/j.micromeso.2015.04.039, 2015.

5. SHEHZAD A., BASHIR M.J.K., SETHUPATHI S., LIM J.-W. An overview of heavily polluted landfill leachate treatment using food waste as an alternative and renewable source of activated carbon, Process Safety and Environment Protection, http://dx.doi.org/10.1016/j. psep.2015.09.005, 2015.

6. XU Q., SIRACUSA G., BECARELLI S., YUAN Q. COD removal from biologically stabilized landfill leachate using Advanced Oxidation Processes (AOPs), Process Safety and Environmental Protection, https://oi.org/10.1016/j. psep.2018.09.014, 2018.

7. CLARKE B.O., ANUMOL T., BARLAZ M., SNYDER M.A. Investigating landfill leachate as a source of trace organic pollutants. Chemosphere, 127, 269, 2015.

8. FOO K.Y., LEE L.K., HAMEED B.H. Preparation of activated carbon from sugarcane bagasse by microwave assisted activation for the remediation of semi-aerobic landfill leachate. Bioresource Technology, 134, 166, 2013.

9. WANG W., TIAN L., ZHOU Y., KANG Y., WANG Q., WANG A. From illite/smectite clay to mesoporous silicate adsorbent for efficient removal of chlortetracycline from water. Journal of Environmental Sciences, 51, 31, 2017.

10. BERGAOUI M., NAKHLI A., BENGUERBA Y., KHALFAOUI M., ERTO A., SOETAREDJO F.E., ISMADJI S., ERNST B. Novel insights into the adsorption mechanism of methylene blue onto organobentonite: Adsorption isotherms modeling and molecular simulation. Journal of Molecular Liquids, doi: 10.1016/j. molliq.2018.10.001, 2018.

11. ZHU L., WANG L., XU Y. Chitosan and surfactant comodified montmorillonite: A multifunctional adsorbent for contaminant removal. Applied Clay Science, 146, 35, 2017.

12. SRINIVASAN R. Advances in application of natural clay and its composites in removal of biological, organic, and inorganic contaminants from drinking water. Advances in Materials Science and Engineering, doi:10.1155/2011/872531, 2011.

13. ZHU R., ZHU L., ZHU J., GE F., WANG T. Sorption of naphthalene and phosphate to the CTMAB-Al13 intercalated bentonites. Journal of Hazardous Materials, 168, 1590, 2009.

14. GILBERTO T.J. Hybrid materials based on bentonite functionalized with amine groups via the hydrolytic sol-gel method. Journal of the Brazilian Chemical Society, 27 (5), 933, 2016.

15. XI Y., FROST R.L., HE H. Modification of the surfaces of wyoming montmorillonite by the cationic surfactants alkyl trimethyl, dialkyl dimethyl, and trialkyl methyl ammonium bromides. Journal of Colloid and Interface Science, 305, 150, 2007.

16. HAN Y.S., MOON J.W., NA Y.H., PARK S.M. Synthesis of clay-amino acid layered nanocomposites by intercalation and their structural stability. Journal of Ceramic Processing Research. 8 (4), 288, 2007.

17. PIRES J., JU'ZK'OW J., PINTO M.L. Amino acid modified montmorillonite clays as sustainable materials for carbon dioxide adsorption and separation, Colloids and Surfaces A: Physicochemical and Engineering Aspects, https://doi.org/10.1016/j.colsurfa.2018.02.019, 2018.

18. KAMALI M., GHAHREMANINEZHAD A. Effect of biomolecules on the nanostructure and nanomechanical property of calcium-silicate-hydrate. Scientific Reports, https://doi.org/10.1038/s41598-018-27746-x, 2018.

19. SHOKRI E., YEGANI R. Novel adsorptive mixed matrix membrane by incorporating modified nanoclay with amino acid for removal of arsenic from water. Journal of Water and Environmental Nanotechnology, 2 (2), 88, 2017.

20. GAO Q., XU Y., WU D., SUN Y., DENG F., SHEN W. Amino acid adsorption on mesoporous materials: Influence of types of amino acids modification of mesoporous materials and solution conditions, Journal of Physical Chemistry B, 112, 2261, 2007.

21. SINGH J., HUANG P.M., HAMMER U.T., LIAW W.K. Influence of citric acid and glycine on the adsorption of mercury (II) by kaolinite under various $\mathrm{pH}$ conditions, Clays and Clay minerals, 44 (1), 4, 1996.

22. SHOKRI E., YEGANI R., GHOFRANI B. Preparation of a new modified clay with amino acid for anionic pollutant removal from water. Bulletin de la Société Royale des Sciences de Liège, 86, 157, 2017.

23. EL ADRA K., GEORGELINE T., LAMBERT J-F., JABER F., TIELENS F., JABER M. Cycteine montmorillonite composites for heavy metal cation complexation: A combined experimental and theoretical study, Chemical Engineering Journal, 314, 406, 2017.

24. SIKDAR D., KATTI D.R., KATTI K.S., MAHANTY B. Influence of backbone chain length and functional groups of organic modifiers on crystallinity and nanomechanical properties of intercalated clay-polycaprolactam nanocomposites, International Journal of Nanotechnology, 6, Nos. 5/6, 2009.

25. BOUCHOUCHA M., JABER M., ONFROY T., LAMBERT J-F., XUE B. Glutamic acid adsorption and transformations on silica, The Journal of Physical Chemistry, 115, 21813, 2011.

26. PAGTALUNAN C.A.M., SUMERA F.C., CONATO M.T. Synthesis and characterization of 12-aminolauric acidmodified montmorillonite for catalytic application, AIP Conference Proceedings, http.//doi.org/10.1063/1.5034552, 2018.

27. BÉE A., OBEID L., MBOLANTENAINA R., WELSCHBILLIG M., TALBOT D. Magnetic chitosan/ clay beads: A magsorbent for the removal of cationic dye from water. Journal of Magnetism and Magnetic Materials, 421, 59, 2017.

28. PUSPITA A., PRATIWI G., FATIMAH I. Chitosanmodified smectite clay and study on adsorption-desorption of urea. Chemical Engineering Transactions, 56 DOI:10.3303/CET1756275, 2017. 
29. LI Y., WANG Z., XIE X., ZHU J., LI R., QIN T. Removal of Norfloxacin from aqueous solution by clay-biochar composite prepared from potato stem and natural attapulgite. Colloids and Surfaces A: Physicochem. Eng. Aspects, 514, 126, 2017.

30. ĐUKIĆ A.B., KUMRIĆ K.R., VUKELIĆ N.S., STOJANOVIĆ Z.S., STOJMENOVIĆ M.D., MILOŠEVIĆ S.S., MATOVIĆ L.LJ. Influence of aging of milled clay and its composite with $\mathrm{TiO}_{2}$ on the heavy metal adsorption characteristics. Ceramics International, 41, 5129, 2015.

31. PARK Y., AYOKO G.A., KURDI R., HORVATH E., KRISTOF J., FROST R.L. Adsorption of phenolic compounds by organoclays: Implications for the removal of organic pollutants from aqueous media. Journal of Colloid and Interface Science, 406, 196, 2013.

32. RATHNAYAKE S.I., XI Y., FROST R.L., AYOKO G.A. Environmental applications of inorganic-organic clays for recalcitrant organic pollutants removal: Bisphenol A. Journal of Colloid and Interface Science, 470, 183, 2016.

33. ZHANG L., ZHANG B., WU T., SUN D., LI Y. Adsorption behavior and mechanism of chlorophenols onto organoclays in aqueous solution. Colloids and Surfaces A: Physicochem. Eng. Aspects, 484, 118, 2015.

34. KATTI K.S., AMBRE A.H., PETERKA N., KATTI D.R. Use of unnatural amino acids for design of novel organo modified clays as components of nanocomposite biomaterials. Philosophical Transactions of the Royal Society A, 368, 1963, 2010.
35. KAUSAR A., NAEEM K., TARIQ M., NAZLI Z-H., BHATTI H.N, JUBEEN F., NAZIR A., IQBAL M. Preparation and characterization of chitosan/clay composite for direct Rose FRN dye removal from aqueous media: comparison of linear and non-linear regression methods. J Mater Res Technol. https://doi.org/10.1016/j. jmrt.2018.07.020, 2018.

36. BHATTACHARYA S.S., AADHAR M. Studies on preparation and analysis of organo-clay nano particles. Research Journal of Engineering Sciences, 3 (3), 10, 2014.

37. AKL M.A., YOUSSEF A.M., AL-AWADHI M.M. Adsorption of acid dyes onto bentonite and surfactantmodified bentonite. J Anal Bioanal Tech, 4, 174. doi:10.4172/2155-9872.1000174, 2013.

38. HE Y.F., ZHANG L., WANG R.M., LI H.R, WANG Y. Loess clay based copolymer for removing $\mathrm{Pb}(\mathrm{II})$ ions. Journal of Hazardous Materials, 227-228, 334-340, 2012.

39. PARANDE A.K., SIVASHANMUGAM A., BEULAH H., PALANISWAMY N. Performance evaluation of low cost adsorbents in reduction of COD in sugar industrial effluent. Journal of Hazardous Materials 168, 800, 2009.

40. FOO K.Y., LEE L.K., HAMEED B.H. Preparation of banana frond activated carbon by microwave induced activation for the removal of boron and total iron from landfill leachate. Chemical Engineering Journal, 223, 604, 2013. 